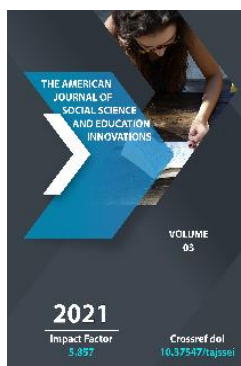

\title{
Stereotypical Questions In The Organization Of The Process Of Teaching Children By Japanese Mothers
}

\author{
Nadira Tashmurzaevna Khalmurzaeva \\ Doctor Of Philological Sciences (Ph.D.), Associate Professor Of Department Of Japanese Philology, \\ Tashkent State University Of Oriental Studies, Tashkent City, Uzbekistan
}

Journal Website:

http://theamericanjour

nals.com/index.php/taj

ssei

Copyright: Original content from this work may be used under the terms of the creative commons attributes 4.0 licence.

\section{ABSTRACT}

In the 1960s, for women raising children, the media called the phrase "教育 ママ" "kyoiku mama" a "mentor for company employees." This includes mothers who act with great responsibility to "successfully pass the rigorous competitive tests required for children, especially boys, to enter high school or college." In Japanese society, the phrase "a father who parenting children" did not appear. It was the "mother of upbringing" "mother Kyoiku" who became a social phenomenon.

In this article, Kyoiku mama ("教育 ママ") is a phraseological phrase that literally translates as "parenting mother." In this article, Kyoiku's mom is viewed as a stereotypical figure exploring maternal parenting for education of children in modern Japanese society.

It also analyzes the impact and power of stereotypes on education problems in Japan.

The article highlights the stereotypes about education in Japan, on the one side, the development of highly qualified young people in Japan, and on the other side, the stress of Japanese children due to the "hell of exams."

\section{KEYWORDS}

Stereotype, Kyoiku mama, education, upbringing, children, Japan, exam. 
Recently, a lot of research has been conducted in different countries on the role of mothers in the education of their children and their psychological impact on their children:

Stereotypical American mothers, such as "stage mothers", who force their children to succeed in show business in Hollywood; "tiger mothers" in Chinese stereotypes, who teach their children to strive for academic and professional success; Jewish mothers as well as intellectual achievement and perfection, are constantly deprived of any flaws. Moreover, it is interesting to note that there are "devoted mothers", who can afford to send their children to medical or law school; and "educated mothers" who put a lot of effort into the development of their children in Japanese stereotypes.

Kyoiku mama (教育まま) is a phraseological phrase that literally translates as "mother of education". Kyoiku mama is a stereotypical figure in modern Japanese society and is used as a term for a mother who forces her child to study at the expense of continuous social and physical development and emotional wellbeing, and who is overzealous in educating her child.

The term “教育まま” used in the media for women raising children in the early 1960s refers to "a mother who raises and nurtures a future employee for the company" [1]. This includes mothers who take great responsibility for "successfully passing the rigorous competitive tests required for children, especially boys, to enter high school or college". No expression has emerged in Japanese society in the sense of a "father who educates men". It was the "mother of education" - "Kyoiku mama" - that became a social phenomenon.

In Japan, the impact of stereotypes on education is so great that it is important to go to a good university to find a good job in the future, but ordinary people, including mothers, are powerless to change this system. As a result, a continuous system has emerged that takes their children to good kindergartens, the best elementary schools, high schools and high schools. In turn, some parents have resorted to immoral or illegal behavior to ensure good results in their children's testing, in order to get them into good kindergartens. It is known that a restaurant owner was found to have paid a \$ 95,000 bribe to enroll a child in the prestigious Aoyama Gakuin Kindergarten for children aged 3 to 4 years.

Kindergarten is an affiliate of an elite university, so parents make every effort to enroll their children in an elite kindergarten. Aoyama Gakuin Kindergarten has about 40 new children a year, and more than 2,000 new children each year. It is known that the entrance exam to this kindergarten is also very difficult. This problem is exacerbated by the idea that Tokyo University graduates are being appointed to the most important positions in business and government.

It is also believed that which college or university a student attends also influences a student's choice of future spouse. Many mothers take special measures to ensure that their children go to a good school because the life of their children depends on which school they go to.

In modern Japan, some mothers devote themselves to raising their children. Nishioka 
Rice added a psychological element to the way she raised young children. In addition to providing a good education according to her psychological approach, the mother should develop emotional and psychological relationships with her children. Nishioka Rice argues that one way to do this is through "skin" - always having close physical contact with the baby. This includes, for example, carrying your child on your back wherever you go, or taking a bath with him or her every day. By protecting the skin, a sense of unity (solidarity and balance, a real basic connection) is achieved between mother and child." [4]

In some parts of Japan, it is very difficult to find a kindergarten, and according to stereotypes, it is considered disrespectful in society for a mother to send her child to kindergarten and not be considered a good mother. In the upbringing of a child, the mother is insufficient and incapable of selfeducation, or in other words, it is selfish for the mother to order her child to do the daily household chores for her own personal purpose.

According to stereotypes, Japanese children make the learning efforts necessary to fulfill their social responsibilities to their families, peers, and communities, forcing them to pay attention to their own efforts, which is the reason for their success. For example: If a Japanese child is not successful in society, he or she is considered to have not worked enough, not to have acted, which does not depend on his or her academic performance. Children are under constant pressure because they are more responsible for their own behavior, for achieving success, so they have to work harder. [5].

The term "Kyoiku mama" is used in other similar contexts. For example, the former
Ministry of International Trade and Industry was once called "Kyoiku mama" because of its approach and initiative to manage the growth of an industry similar to the state definition of raising children. [6]

Housewives are surrounded by incentive actions by popular media. Daytime television shows, magazines, goods and services for mothers will be primarily focused on home improvement and child rearing. Thus, Japanese mothers take maternity work very seriously and include "eating and sleeping three times a day" when their leisure time is generally explained.

There are preparatory schools and higher education curricula throughout Japan, but they are relatively rare in rural areas and concentrated in cities.

"Kyoiku mama" mothers are middle-class families, and middle-class women educate the next generation of middle-class children. In a speech at the Mitsukoshi Children's Exhibition in 1909, Inazo Shin Vatato, the principal of the primary school, stated that "the country must begin with the upbringing of mothers, not infants."

In post-war Japan, mothers became the founders of a new, child-centered world sealed to middle-class values. In connection with the success of mothers in educating their children, according to the stereotype, women were expected to be "good wives and wise mothers" and to be the most important person in raising children to become adults in the future.

Since confidence in education was a necessary condition for social development in the early 2oth century, educated mothers actively considered access to education systems, especially for boys and girls, in order to 
actively improve the social status of their families. The competition for high school and girls to take entrance exams to prestigious high schools is intensifying, and a social phenomenon known as "exam hell" is emerging. For an educated mother, turning a child into an excellent student begins when a child enrolls in elementary school when he or she is 6 years old, and a child cannot achieve all aspects of teaching or a successful career without an educated mother. Working mothers are less active in educating their children than middle-class mothers. An ethnographic study by Shimizu and Tokuda (1991) described a high school in Osaka facing constant academic challenges due to the working class. This study describes teachers 'efforts to improve student achievement, conduct tests, facilitate monthly discussions with teachers, paint walls to improve the learning environment, and limit time in extracurricular activities. At the same time, the number of high school students improved slightly, but their performance was lower than the national average. This study found that students 'academic problems were closely related to their home environment. Reasons were given that the majority of students did not receive education from their parents and did not participate in the education of their children [7].

The modern "Kyoiku mama" is the mother of modern education

Many Japanese mothers spend a lot of time transferring their children from one entrance exam to another, but in the entrance exams to the National University in Tokyo, most mothers take the exam with their children. According to statistics, they visit the place, stay at a nearby hotel upon arrival, and even make sure their children are not late for the exam at the last minute.
Some mothers start teaching their children at a very early age, and a 30-year-old mother from Japan says, "This is my first daughter. Also, I didn't know how to play with it and help it grow. "She gave her 6-month-old daughter to a kindergarten in Tokyo. Other kindergarten principals claim that schools for children over the age of 1 help nurture and develop children's curiosity by 'cleaning mandarins or collecting and painting snow' [8].

According to stereotypes, the ability of Japanese mothers to raise their children often values their big neighborhood debut or park debut. Here, the mother has to hold an introductory event for her child in a nearby garden "for the consent of the neighbors".

Mothers send their children to pre-school schools. Kids can stay in high school until $10 \mathrm{pm}$ or 11pm, but there are more than 35,000 schools in Japan that take university exams. In addition to day school, children take calligraphy, keyboard, arithmetic, or kendo lessons in school clubs.

The Ministry of Education, Culture, Sports, Science and Technology has acknowledged that the education system and parental pressure place a heavy burden on children. Education reforms carried out by the Ministry of Education in the early 1970s demanded equality of the Japanese school system. To reduce the pressure on students in exams, the Ministry of Education has reduced teaching hours and carried out non-academic activities such as closing primary and secondary schools and preparatory courses. [9] In 2002, the central government again reduced teaching hours, reduced subject content, and introduced a new curriculum to increase learning interests and motivation for all students in all public elementary schools. The Ministry of Education has issued an official 
document stating that children do not have the opportunity to "be closely connected with nature, to be amazed, to respect life and to understand the importance of hard work to learn to overcome difficulties". [10].

In post-war Japan in the 1950s, "Accelerating Education Programs" was a national task. Children in this period had to be different from their kindergarten peers at an early age if they wanted to enter a prestigious university. By the mid-1970s, as children tried to achieve this, there was a need for specialized schools. Seventy percent of students continued to attend kindergarten for long periods of time. In the 1980s, a number of school-related suicides began. Elementary and high school students committed suicide because they failed the entrance exams. In 2002, the Japanese Ministry of Education, Culture, Sports, Science and Technology pulled out 30 percent of its core curriculum under pressure from reforms. This gave students more time to study in groups according to the paths they chose [10].

What is the average cost of education for a child?

According to the "Basic Survey of Schools in the First Year of Reyva" conducted by the Ministry of Education, Culture, Sports, Science and Technology, the enrollment rate was $82.8 \%$ and the enrollment rate in universities and youth colleges was $58.1 \%$. this is the highest of both. Therefore, it is more beneficial for parents to prepare for approximately 16 years of tuition expenses from elementary school to graduation from university.

Now, we know how much each educational institution costs from a survey conducted by the Ministry of Education, Culture, Sports, Science and Technology $\left({ }^{*} 1\right)$.

The table below shows the average costs of public and private education from primary school to high school for each educational institution.

"Basic statistics of schools in 2018 (basic report on schools)" created by revising the table "Total tuition costs by type of school" of the Ministry of Education, Culture, Sports, Science and Technology.

The costs associated with children's education are almost the same as the cost of education. The survey included "school tuition expenses" paid from home to attend school, "school lunch expenses" called meals, expenses for tram schools and classes, and "extracurricular activities". It is divided into two.

The total cost of tuition from primary school to high school is $4,765,017$ yen, and for all public participation is $16,721,178$ yen, a difference of 11,96516 yen.

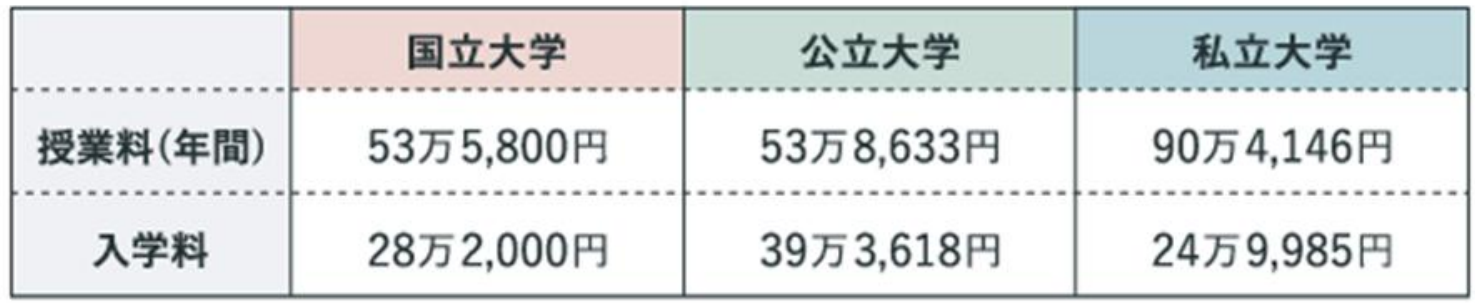

※国立大学は国が示す標準額。 ※公立·私立大学の額は平均值で、公立大学入学料は地域外からの入学者の平均。 
How much does the university cost?

The costs for the first year of admission to national, public, and private universities are as follows.

If this is added to the cost of tuition from primary school to high school, it is $7,313,167$ yen in all public schools (7,190,217 yen) if it is paid in all private schools.

Even at the same university, the annual tuition fee varies depending on the faculty the student is studying at, but in general, tuition and entrance fees are higher for the natural sciences than for the social sciences. Most importantly, if a student is in medical school or graduate school, he or she must cover all of the 6-year tuition costs himself or herself.

In addition to tuition fees, if a student attends a university far away from his or her place of birth, he or she will also have to pay a monthly rent, dormitory, and living expenses. Therefore, when enrolling in school fund insurance, there are many who receive a onetime tuition fee when entering university at the age of 18 and a majority who plan to split tuition during the enrollment period between the ages of 18-22. Apparently. In any case, as the child grows older, the amount of money spent on education will also increase.

(* 1) Source: "General Education Expenditures by School Types" from "Basic School Statistics 2018 (Basic School Survey Report)" by the Ministry of Education, Culture, Sports, Science and Technology.

\begin{tabular}{|c|c|c|c|}
\hline & 国立大学 & 公立大学 & 私立大学 \\
\hline 授業料(年間) & 53万5,800円 & 53万8,633円 & 90万4,146円 \\
\hline 入学料 & 28万2,000円 & 39万3,618円 & 24万9,985円 \\
\hline
\end{tabular}

※国立大学は国が示す標準額。 ※公立・私立大学の額は平均值で、公立大学入学料は地域外からの入学者の平均。 


\begin{tabular}{|c|c|c|c|c|c|}
\hline \multicolumn{6}{|c|}{ 公立 } \\
\hline & 内訳 & 小学校 & 中学校 & 高等学校(全日) & \\
\hline \multirow{4}{*}{$\begin{array}{c}\text { 1年当たりり } \\
\text { の総額 }\end{array}$} & 学校教育費 & 6 万 $3,102 円$ & 13万8,961円 & 28万487円 & \\
\hline & 学校給食費 & 4 万 3,728 円 & 4万 2,945 円 & - & \\
\hline & 学校外活動費 & 21万4,451円 & 30万6,491円 & 17万6,893円 & \\
\hline & 学習費 & 32万1,281円 & 48万8,397円 & 45 万7,380円 & \\
\hline \multicolumn{2}{|c|}{ 在学中総頶 } & 192万 7,686円 & 146万5,191円 & 137万2,140円 & 476 万, $017 \AA$ \\
\hline
\end{tabular}

\begin{tabular}{|c|c|c|c|c|c|}
\hline \multicolumn{6}{|c|}{ 私立 } \\
\hline & 内訳 & 小学校 & 中学校 & 高等学校(全日) & \\
\hline \multirow{4}{*}{$\begin{array}{c}\text { 1年当たり } \\
\text { の総類 }\end{array}$} & 学校教育費 & 90万4,164円 & 107 万 1,438 円 & 71 万9,051円 & \\
\hline & 学校給食費 & 4万 7,638円 & 3,731円 & - & \\
\hline & 学校外活動費 & 64万6,889円 & 33万1,264円 & 25 万 $860 円$ & \\
\hline & 学習費 & 159万8,691円 & 140 万 6,433 円 & 96万9,911円 & \\
\hline \multicolumn{2}{|c|}{ 在学中総頶 } & 959万2,146円 & 421万9,299円 & 290万 $9,733 円$ & 1,672万 $1,178 \mathrm{円}$ \\
\hline
\end{tabular}

In short, Kyōiku mama (教育まま) is a phrase that can be understood both positively and negatively, as it is a stereotypical figure in modern Japanese society, which on the one hand serves to lead the child to quality education, on the other hand Kyōiku mama is considered as the mother, who influences pressure to the child's social, physical and psychological development.

Kyoiku-mama is feared by her children, and the press has accused some Kyoiku-mamas of their children's school phobias and suicide. The mothers of children who did not teach enough and did not pass the exams have become a stereotype of envy and anger towards Kyoiku-mamas.
Thus, in Japan, the issue of educating children is given great importance from the Japanese government to the parental level. In Japan, the phenomenon of "kyoiku mama" and the issues of children's education are manifested as a social phenomenon that has become stereotypes.

While stereotypes about education in Japan, on the one hand, Japanese children bring up highly qualified and talented young people, on the other hand, it has become clear that Japanese children also experience stress due to the "hell of exams".

\section{REFERENCES}


1. Kato, Etsuko. The Tea Ceremony and Women's Empowerment in Modern Japan: Bodies Re-presenting the Past. London: Routledge, 2004.

2. 落合恵美子『21世紀家族へ

家族の戦後体制の見かた・超えかた

』有斐閣<有斐閣選書>、1994年

3. White, Merry I. Perfectly Japanese: Making Families in an Era of Upheaval. Berkeley: University of California Press, 2002.

4. Elliot, Julian. Bempechat, Janine. Learning in Culture and Context. San Francisco: Jossey-Bass, 2002.

5. エズラ・ヴォーゲル Japan as Number One, Harvard University Press, 1979, p. 70 (邦訳『ジャパン・アズ・ナンバ 一ワン』TBSブリタニカ、1979年）

6. Jones, Mark Alan. Children as treasures: Childhood and the middle class in early twentieth-century Japan. Diss. Columbia University, 2001. Proquest Digital Dissertations. ProQuest. University of Texas at Austin Libraries 30 October 2007

7. Joseph, Joe. The Japanese: Strange But Not Strangers. London: Viking, 1993.

8. Yamamoto, Yoko. Unequal beginnings: Socioeconomic differences in Japanese mothers' support of their children's early schooling. Diss. University of California, Berkeley, 2006. ProQuest Digital Dissertations. ProQuest. University of Texas at Austin Libraries 30 Oct. 2007

9. Joseph, Joe. The Japanese: Strange But Not Strangers. London: Viking, 1993.

10. Nathan, Jonathan. Japan Unbound. New York: Houghton Mifflin Company, 2004. 